\title{
Erratum to: 'The Memory Aid study: protocol for a randomized controlled clinical trial evaluating the effect of computer-based working memory training in elderly patients with mild cognitive impairment $(\mathrm{MCl})^{\prime}$
}

\author{
Marianne M. Flak ${ }^{1,2^{*}}$, Susanne S. Hernes ${ }^{1}$, Linda Chang ${ }^{2}$, Thomas Ernst ${ }^{2}$, Vanessa Douet ${ }^{2}$, Jon Skranes ${ }^{3,4}$ \\ and Gro C. C. Løhaugen ${ }^{3,4}$
}

Unfortunately, the original version of this article [1] contained an error. Three authors were omitted from the author list and have been included here so that the complete author list reads as: Marianne M Flak ${ }^{1,2 *}$, Susanne S. Hernes ${ }^{1}$, Linda Chang ${ }^{2}$, Thomas Ernst ${ }^{2}$, Vanessa Douet $^{2}$, Jon Skranes ${ }^{3,4}$, and Gro C. C. Løhaugen ${ }^{3,4}$.

Another consequence of the first mistake is that the sections about MRI ( $4^{\text {th }}$ section page 3$)$ and genotyping (last section on page 3 and first section on page 4) contain some errors.

The MRI section should read as follows:

Magnetic resonance brain imaging

The patients will undergo brain MRI scanning at baseline and at 1 and 4 months post-training, using an optimized protocol. Following a pilot scan, a three-dimensional (3D) magnetization-prepared rapid gradient echo (MP-RAGE) scan will be performed (sagittal, echo time $3.47 \mathrm{~ms}$, repetition time $2400 \mathrm{~ms}$, TI $1000 \mathrm{~ms}$, flip angle (FA) 8 degrees, $1.2 \mathrm{~mm}$ resolution covering the whole brain).

Diffusion tensor imaging (DTI) scan will be performed (axial (non-oblique), 68 slices, field of view $=240 \mathrm{~mm}$, $2.5 \mathrm{~mm}$ slices without gap; $2.5 \times 2.5 \mathrm{~mm}$ in-plane resolution; repetition time $9.500 \mathrm{~ms}$, echo time $91 \mathrm{~ms}$, two averages, diffusion $\left\{\mathrm{b}=0\right.$ and $\left.1000 \mathrm{~s} / \mathrm{mm}^{2}\right\}, 30$ diffusion directions. In addition, a 3D-T2 space dark fluid (FLAIR)

\footnotetext{
* Correspondence: marianne.moretro.flak@sshf.n

'Department of Medicine, Geriatric Unit, The Memory Clinic, Sørlandet Hospital, Arendal, Norway

2Department of Medicine, John A. Burns School of Medicine, The Queen's

Medical Center, Honolulu, HI, USA

Full list of author information is available at the end of the article
}

image (sagittal, echo time $335 \mathrm{~ms}$, repetition time $5000 \mathrm{~ms}$, TI $1800 \mathrm{~ms}$, turbo factor 242, $1.2 \mathrm{~mm}$ resolution covering the whole brain) and a $\mathrm{T}^{*}$ image (axial TE $25 \mathrm{~ms}$, TR $830 \mathrm{~ms}$, flip angle 20 degrees) will be acquired during the initial scan for clinical evaluation to exclude microbleeds. Total scanning time for the initial scan will be close to 30 minutes. The follow-up scans will be under 25 minutes. All scans will be reviewed qualitatively by a radiologist to screen for possible brain lesions or structural abnormalities. By using tract-based spatial statistics (TBSS or DTIStudio) axial, medial and mean diffusivity values will be measured in white matter tracts involved in the working memory network before and after training. Automated morphometry to evaluate cortical thickness, surface area, and total gray and white matter volumes, as well as deep nuclei volumes will be performed using Freesurfer.

The section about genotyping should read as follows:

Biological/Biochemical Samples, Study Biobank and DNA Collection

DNA will be extracted from saliva collected in Oragene Self collection Kit (DAN Genoteck, Inc. Ottawa, Ontario, Canada). Genomic DNA will be subjected to Restriction Fragment Length Polymorphism analyses (RFLP-PCR) for genotype analyses of $A P O E \varepsilon$ (rs429358 and rs7412) and LMX1A (rs4657412). Approximately $3 \mathrm{ng}$ of genomic DNA will be amplified by PCR using the primers LMX-5':5'-CTCGCCTCCAGGAA TGGGTGTTGTA-3' and LMX-3': 5'-GCCACGAGGAACTTGTGAGAGGG TT-3' for $L M X 1 A$ and APO-5' and APO-3' for APOEE 
(Andres et al., 2011) with the following conditions: denaturation at $94{ }^{\circ} \mathrm{C}$ for 5 minutes, followed by 30 cycles at $94{ }^{\circ} \mathrm{C}$ for 30 seconds, annealing at $64{ }^{\circ} \mathrm{C}$ for 30 seconds and extending at $72{ }^{\circ} \mathrm{C}$ for 30 seconds. Then $15 \mu \mathrm{l}$ of the amplification PCR products will be digested directly by $2.5 \mathrm{U}$ of restriction enzymes MslI (R0571S, New England Biolabs, Beverly, MA) for 2 hours at $37{ }^{\circ} \mathrm{C}$, and by HaeII (R0107S, New England Biolabs, Beverly, MA, USA) and AflIII (R0541S, New England Biolabs, Beverly, MA, USA) overnight at $37{ }^{\circ} \mathrm{C}$. The digested PCR products will then be analyzed on $4 \%$ agarose gel and visualized using GelGreen ${ }^{\text {nu }}$ Nucleic Acid Gel Stain (89139-144, Biotium, Hayward, CA).

\section{Author details}

${ }^{1}$ Department of Medicine, Geriatric Unit, The Memory Clinic, Sørlandet Hospital, Arendal, Norway. ${ }^{2}$ Department of Medicine, John A. Burns School of Medicine, The Queen's Medical Center, Honolulu, HI, USA. ${ }^{3}$ Department of Pediatrics, Sørlandet Hospital, Arendal, Norway. ${ }^{4}$ Department of Laboratory Medicine, Children's and Women's Health, Norwegian University of Science and Technology, Trondheim, Norway.

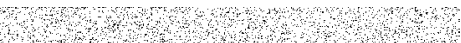

\section{References}

1. Flak MM, Hernes SS, Chang L, Ernst T, Douet V, Skranes J, et al. The Memory Aid study: protocol for a randomized controlled clinical trial evaluating the effect of computer-based working memory training in elderly patients with mild cognitive impairment (MCI). Trials. 2014;15:156.

Submit your next manuscript to BioMed Central and we will help you at every step:

- We accept pre-submission inquiries

- Our selector tool helps you to find the most relevant journal

- We provide round the clock customer support

- Convenient online submission

- Thorough peer review

- Inclusion in PubMed and all major indexing services

- Maximum visibility for your research

Submit your manuscript at www.biomedcentral.com/submit 